\title{
PENERAPAN PEMBELAJARAN PROBLEM SOLVING UNTUK MENINGKATKAN HASIL BELAJAR FISIKA SISWA KELAS XI IPA.2 SMAN 6 PEKANBARU
}

\author{
Lasma Br Hotang \\ Guru Fisika SMAN 6 Pekanbaru \\ lasmahotang@gmail.com
}

\begin{abstract}
ABSTRAK: Tujuan penelitian ini adalah untuk meningkatkan hasil belajar fisika siswa kelas XI IPA2 SMAN 6 Pekanbaru melalui problem solving. Hasil observasi proses pembelajaran fisika terlihat hasil ulangan yang diperoleh siswa hanya 8 dari 33 (24\%) peserta didik yang tuntas sedangkan 25 (76\%) peserta didik belum mencapai KKM. Untuk menyelesaikan permasalahan tersebut peneliti menggunakan model pembelajaran Problem Solving untuk meningkatkan hasil belajar didik. Penelitian ini merupakan penelitian tindakan kelas yang terdiri 2 siklus dan akhir setiap siklus dilakukan ulangan untuk melihat peningkatan motivasi dan hasil belajar yang terjadi. Hasil penelitian ini menunjukan terjadi peningkatan pembelajaran fisika siswa. Hal itu terlihat dari Rata-rata ulangan harian untuk seluruh peserta didik yang tuntas 83,33 dengan nilai tertinggi 95 dan rata-rata ulangan harian yang belum tuntas 63,33 nilai terendah 55. Rata-rata nilai ulangan harian seluruhnya 81,51 kategori baik. Maka dapat disimpulkan bahwa penerapan model pembelajaran problem solving dapat meningkatkan hasil belajar fiska bagi peserta didik kelas XI IPA.2 SMAN 6 Pekanbaru.
\end{abstract}

Kata Kunci: problem solving, model pembelajaran, fisika 


\title{
THE USE OF PROBLEM SOLVING METHOD TO IMPROVE THE STUDENTS ABILITY IN PHISIC CLASS XI IPA.2 SMAN 6 PEKANBARU
}

\begin{abstract}
This research aimed to improve the ability of the phisic subject XI IPA2 SMAN 6 Pekanbaru students. Students were not encouraged to develop critical thinking skills where the results obtained are only 8 out of 32 (24\%) students who complete while the other 25 (76\%) students have not yet reached KKM (Minimum Completeness Criteria). The research method used was the Classrom Action Research (CAR) which consist of 2 cycles. Before the treatment was performed, the students were given a pre-test, and after the treatment a post-test was administered. The research findings The average daily test scores were 68.33 enough categories and in the second cycle the number of students whose grades were complete were 30 people (91\%) with "Good" criteria and the number of unfinished students was 3 (9\%). The average daily test for all completed students was 83.33 with the highest score of 95, and the average daily test for the unfinished 63.33 with the lowest score of 55. The overall daily test score was 81.51 in the good category. Then it can be concluded that the application of problem solving learning models can improve learning outcomes of physics for students in class XI IPA 2 of SMAN 6 Pekanbaru.
\end{abstract}

Key word: problem solving,, learning method, phisic.

\section{PENDAHULUAN}

Prinsip pendidikan yang kita anut merupakan pendidikan seumur hidup (The Life Long Education) yang tegas mengisyaratkan bahwa pendidikan bukanlah aktivitas lembaga saja namun individunya harus memiliki potensi untuk membentuk kepribadian kearah yang diinginkan. Berbagai usaha dilakukan pemerintah, misalnya perbaikan kurikulum, melengkapi buku-buku di sekolah, peningkatan kemampuan guru melalui penataranpenataran dan pendampingan sekolah-sekolah untuk setiap jenjang pendidikan melalui pengawasan yang dilakukan pengawas sekolah yang sudah ditunjuk oleh pemerintah.

Berbicara tentang proses belajar mengajar maka kita tidak terlepas dari peranan guru sebagai tenaga pendidik. Guru sebagai fasilitator dan motivator sangat besar peranannya dalam mencapai tujuan yang telah ditetapkan dalam proses belajar mengajar. (Sanjaya 2008: 23). Untuk itu guru harus membentuk suasana lingkungan yang dapat membentuk atau mengubah struktur kognitif peserta didik dengan menyediakan pengalaman belajar bagi peserta didik. Proses pembelajaran menuntut aktivitas peserta didik secara penuh untuk mencari dan menemukan sendiri konsep materinya. Peserta didik 
yang hidup di zaman ini menghadapi tantangan yang lebih besar dari segi kesiapannya untuk bersaing dimasyarakat. Untuk itu guru dituntut mampu menggali kemampuan peserta didik secara maksimal.

Hal ini dimungkinkan jika guru juga meningkatkan kemampuannya dalam menemukan metode dan strategi baru yang lebih tepat sehingga peserta didik menaruh perhatian dan motivasi yang lebih besar, dengan demikian ilmu yang diperoleh peserta didik adalah dari pengalaman belajarnya sendiri akan lebih tahan lama dan pengetahuan yang dipahami dapat dipergunakan menyelesaikan masalah dalam kehidupan sehari-hari.

Salah satu masalah yang dihadapi dunia pendidikan adalah masalah lemahnya proses pembelajaran. Dalam proses pembelajaran di kelas anak kurang didorong untuk mengembangkan kemampuan berpikir. Menurut Sanjaya (2008: 1) bahwa belajar bukan semata-mata proses menghapal sejumlah fakta, tetapi suatu proses interaksi secara sadar antara individu dengan lingkungannya.

Melalui proses ini sedikit demi sedikit peserta didik akan berkembang secara utuh, baik kognitif, afektif dan psikomotor sehingga dengan keutuhan pengetahuan itu akan mampu menyelesaikan masalah. Banyak guru hanya mengutamakan aspek kognitif peserta didik saja sehingga proses pembelajaran di dalam kelas diarahkan kepada kemampuan anak untuk menghafal informasi, otak anak dipaksa untuk mengingat dan menimbun berbagai informasi tanpa dituntut untuk memahami informasi yang diingatnya itu untuk menghubungkan dengan kehidupan sehari-hari. Sanjaya (2010) mengatakan untuk apa peserta didik menguasai materi pelajaran sebanyak-banyaknya kalau ternyata materi yang dikuasainya itu tidak berdampak terhadap perubahan perilaku dan kemampuan peserta didik dalam menyelesaikan masalah yang berkaitan dengan berkaitan dengan konsep keilmuan fisika.

Jika dilihat kenyataan dilapangan hasil pemahaman peserta didik tentang konsep fisika di sekolah masih sangat rendah, hal ini tergambar dari ulangan harian ke-1 dengan sub pokok bahasan Kesetimbangan benda tegar. Hasil data yang diperoleh ada delapan (8) dari 33 (24\%) peserta didik memiliki nilai mencapai Kriteria Ketuntasan Minimal (KKM), sedangkan sisanya 25 peserta didik (76\%) masih belum mencapai KKM. Hal itu disebabkan beberapa faktor antara lain peserta didik kurang bersemangat dalam belajar, karena menganggap Fisika identik dengan banyak rumus dan selalu banyak hitunghitungannya.

Guru juga sering melaksanakan pembelajaran tidak efektif dimana guru hanya menugaskan kepada peserta didik secara berkelompok untuk melakukan diskusi yang biasanya hanya didominasi oleh satu atau dua orang tertentu. Diskusi seperti ini sering berakhir dengan penjelasan materi yang didominasi guru karena kurangnya interaktif 
dalam diskusi dan peserta didik yang tidak aktif hanya berperan sebagai penonton. Akibatnya apa yang diharapkan dari tujuan pembelajaran tidak tercapai. Pada umumnya ketika guru memberikan kesempatan pada peserta didik untuk bertanya, tidak ada peserta didik mau bertanya dan ketika guru mengajukan pertanyaan biasanya yang mencoba menjawab hanya 1 atau 2 orang.

Untuk memecahkan masalah diatas penulis berinisiatif untuk membuat penelitian tindakan kelas dengan model pembelajaran problem solving (berbasis masalah). Pembelajaran problem solving merupakan suatu pendekatan dalam pembelajaran yang membantu peserta didik untuk menemukan masalah dari suatu peristiwa yang nyata, mengumpulkan informasi melalui strategi yang telah ditentukan sendiri untuk peristiwa yang nyata. Dari model pembelajaran problem solving akan terbentuk peserta didik yang mampu menghadapi masalah, menganalisisnya mengapa dapat terjadi dan apa jalan keluarnya, serta mampu mengkaitkan konsep-konsep ilmu fisika dengan masalah yang sedang dihadapi atau yang sedang dipelajari. Melalui proses pembelajaran problem solving peserta didik dilatih mengembangkan keterampilan memecahkan masalah, mendorong peserta didik belajar berkolaborasi.

Pemecahan suatu masalah sangat membutuhkan kerjasama dan sharing antar anggota. Proses pembelajaran ini memberi pengaruh pada peserta didik sehingga berfikir secara kritis dan kreatif. Menurut Riyanto (2009: 144) menjelaskan "bahwa guru harus menyediakan suasana dimana pada peserta didik diarahkan agar keinginan belajar untuk memahami dan menerapkan pengetahuan lebih dibangun, maka harus bekerja memecahkan masalah menemukan segala sesuatu untuk dirinya, berusaha dengan ide-ide”. Guru dapat memberikan kesempatan kepada peserta didik untuk menentukan atau menerapkan ide-ide mereka sendiri untuk belajar.

Guru dapat memberi peserta didik anak tangga yang membawa peserta didik ke pemahaman yang lebih tinggi dengan catatan peserta didik sendiri harus memanjat anak tangga tersebut. Anak tangga yang dimaksud salah satu dengan memecahkan masalah. Berdasarkan karakteristik keunggulan model pembelajaran problem solving yang telah diuraikan maka Penulis bermaksud melakukan Penelitian Tindakan Kelas (PTK) guna meningkatkan hasil belajar Fisika peserta didik di kelas XI IPA. 2 melalui penggunaan model pembelajaran problem solving dengan judul "Efektivitas Model Pembelajaran Problem Solving Untuk Meningkatkan Hasil Belajar Fisika Peserta didik Kelas XI IPA.2 SMAN 6 Pekanbaru Semester Ganjil T.A 2017/2018 


\section{Model Pembelajaran Problem Solving}

Menurut Good dan Brophy (dalam Hamzah 2010: 15) "belajar merupakan suatu proses atau interaksi yang dilakukan seseorang dalam memperoleh sesuatu yang baru dalam bentuk perubahan perilaku sebagai hasil dari pengalaman itu sendiri”. Belajar yang dilakukan dengan mengacu terhadap permasalahan yang ada di sekitar peserta didik. Menurut J. Mursell dan Nasution (2008:20) mengatakan bahwa "berhasil tidaknya belajar tergantung pada makna dari apa yang dipelajari" Pelajaran itu bermakna jika masalah itu rill atau berharga atau bagi sipelajar, dan memiliki hubungan yang esensial antara bagian bagiannya.

Menurut Sanjaya (2008: 216) hakikat masalah adalah perbedaaan antara situasi nyata dan kondisi yang diharapkan. Kesenjangan tersebut, atau kecemasan. rasakan dari adanya keresahan, keluhan, kerisauan. Oleh karna itu maka materi pelajaran atau topik tidak terbatas pada materi pelajaran yang bersumber dari buku saja tetapi masalah itu harus rill Menurut Riyanto (2009: 285) menjelaskan pembelajaran berbasis masalah model pembelajaran yang dapat membangun di sekitar suatu masalah nyata dan kompleks yang secara alami memerlukan pemeriksaan, panduan informasi dan refleksi, membuktikan hipotesis sementara, dan diformulasikan untuk dicarikan solusinya. Bloom 2004 (dalam Riyanto 2009: 285). Pemecahan masalah dilakukan dengan pola kolaborasi dan menggunakan kemampuan berpikir tingkat tinggi yakni kemampuan analisis-sintesis dan evaluasi. Masalah yang disajikan adalah masalah yang memiliki konteks dengan dunia nyata. Semakin dekat dengan dunia nyata, akan semakin baik pengaruhnya pada peningkatan kecakapan peserta didik.

Menurut Bruner dalam Trianto (2009) bahwa "berusaha sendiri untuk mencari pemecahan masalah serta pengetahuan yang menyertainya, menghasilkan pengetahuan yang benar-benar bermakna". Suatu konsekuensi yang logis, karena dengan berusaha untuk mencari pemecahan masalah secara mandiri akan memberikan suatu permasalahan yang konkret, dengan pengalaman tersebut dapat digunakan pula memecahkan masalahmasalah serupa, karena pengalaman itu memberikan makna tersendiri bagi peserta didik. Sedangkan menurut Arendes dalam Trianto (2009) bahwa pengajaran berdasarkan masalah merupakan suatu pendekatan pembelajaran dimana peserta didik mengerjakan masalah yang autentik dengan maksud untuk menyusun pengetahuan mereka sendiri, mengembangkan kemandirian dan percaya diri.

Dari teori diatas dapat diambil suatu pemahaman model pembelajaran problem solving adalah pembelajaran yang diarahkan untuk menyelesaikan masalah. Suatu masalah yang menarik dan bermakna. Menurut Sanjaya (2008:15) "Permasalahan tersebut bisa 
diambil dari buku teks atau dari sumber-sumber lain misalnya dari peristiwa yang terjadi di lingkungan sekitar,dari peristiwa dalam keluarga atau dari peristiwa kemasyarakatan".

Prinsip-prinsip proses pembelajaran berbasis masalah menurut Suharto (2015: 30) adalah

1. Konsep dasar yaitu pada pembelajaran ini fasilatator dapat memberikan konsep dasar, petunjuk, referensi

2. Pendefenisian masalah yaitu fasilator menyampaikan masalah dan semua anggota kelompok akan mengungkapkan pendapat atau ide untuk memberikan altenatif pemecahan masalah

3. Pembelajaran mandiri yaitu peserta didik mencari informasi untuk mengembangkan pemahaman

4. Pertukaran pengetahuan yaitu presentasi akhir dalam kelas dengan mengakomodasi masukan dari pleno dan bersama guru menentukan kesimpulan akhir.

Menurut Ibrahim dalam Trianto (2009) peran guru dalam langkah pembelajaran problem solving adalah sebagai berikut:

a. Mengajukan masalah atau mengorientasikan peserta didik kepada masalah autentik

b. Melakukan pengamatan atau melakukan eksperimen atau percobaan.

c. Memfasilitasi dialog peserta didik.

Menurut Suharto (2015: 31) Langkah pelaksanaan pembelajaran berbasis masalah:

\section{FASE-FASE}

\section{PERILAKU GURU}

\begin{tabular}{|c|c|}
\hline $\begin{array}{l}\text { Fase } 1 \\
\text { Orientasi peserta didik } \\
\text { kepada masalah. }\end{array}$ & $\begin{array}{l}\text { Menjelaskan tujuan pembelejaran, menjelaskan } \\
\text { logistik yg dibutuhkan. } \\
\text { Memotivasi peserta didik untuk terlibat aktif dalam } \\
\text { pemecahan maslah yang dipilih }\end{array}$ \\
\hline $\begin{array}{l}\text { Fase } 2 \\
\text { Mengorganisasikan } \\
\text { peserta didik }\end{array}$ & $\begin{array}{l}\text { Membantu peserta didik mendefinisikan dan } \\
\text { mengorganisasikan tugas belajar yang berhubungan } \\
\text { dengan masalah tersebut. }\end{array}$ \\
\hline $\begin{array}{l}\text { Fase } 3 \\
\text { Membimbing } \\
\text { penyelidikan individu dan } \\
\text { kelompok. }\end{array}$ & $\begin{array}{l}\text { Mendorong peserta didik untuk mengumpulkan informs } \\
\text { yang sesuai, melaksanakan eksperimen untuk } \\
\text { mendapatkan penjelasan dan pemecahan masalah. }\end{array}$ \\
\hline
\end{tabular}




\begin{tabular}{ll}
\hline $\begin{array}{l}\text { Fase 4 } \\
\text { Mengembangkan dan } \\
\text { menyajikan hasil karya }\end{array}$ & $\begin{array}{l}\text { Membantu peserta didik dalam merencanakan dan } \\
\text { menyiapkan karya yang sesuai seperti laporan, model } \\
\text { dan berbagi tugas dengan teman. }\end{array}$ \\
\hline Fase 5 & Mengevaluasi hasil belajar tenatng materi yang telah \\
Menganalisa dan & dipelajari / meminta kelompok presentasi hasil kerja. \\
mengevaluasi proses & \\
pemecahan masalah. & \\
\hline
\end{tabular}

Setelah fase-fase model pembelajaran problem solving diuraikan maka disini akan dijelaskan referensi penilaian yang digunakan. Penilaian pembelajaran dengan berbasis masalah dilakukan dengan authentic assessment. Penilaian dapat dilakukan dengan portofolio yang merupakan kumpulan yang sistematis pekerjaan-pekerjaan peserta didik yang dianalisis untuk melihat kemajuan belajar dalam kurun waktu tertentu dalam kerangka pencapaian tujuan pembelajaran. Penilaian yang relevan dalam pembelajaran berbasis masalah antara lain berikut ini.

1). Penilaian kinerja peserta didik

Pada penilaian kinerja ini, peserta didik diminta untuk unjuk kerja atau mendemontrasikan kemampuan melakukan tugas-tugas tertentu, seperti menulis karangan, melakukan suatu eksperimen, menginterpretasikan jawaban pada suatu masalah,memainkan suatu lagu, atau melukis suatu gambar.

\section{2). Penilaian portofolio peserta didik}

Penilaian portofolio adalah penilaian berkelanjutan yang didasarkan pada kumpulan informasi yang menunjukkan perkembangan kemampuan peserta didik dalam suatu periode tertentu. Informasi perkembangan peserta didik dapat berupa hasil karya terbaik peserta didik selama proses belajar, pekerjaan hasil tes, piagam penghargaan, atau bentuk informasi lain yang terkait kompetensi terntentu dalam suatu mata pelajaran.

\section{3). Penilaian potensi belajar}

Penilaian yang diarahkan untuk mengukur potensi belajar peserta didik yaitu mengukur kemampuan yang dapat ditingkatkan dengan bantuan guru atau teman-temannya yang lebih maju. Pembelajaran berbasis masalah yang memberi tugas-tugas pemecahan masalah memungkinkan peserta didik untuk mengembangkan dan mengenali kesiapan belajarnya. 


\section{4). Penilaian usaha kelompok}

Menilai usaha kelompok seperti yang dilakukan pada pembelajaran kooperatif dapat dilakukan pada pemlajaran berbasis masalah. Penilaian usaha kelompok mengurangi kompetisi merugikan yang sering terjadi, misalnya membandingkan peserta didik dengan temannya. Penilaian dan evaluasi yang sesuai dengan model pembelajaran berbasis masalah adalah menilai pekerjaan yang dihasilkan oleh peserta didik sebagai hasil pekerjaan mereka dan mendiskusikan hasil pekerjaan secara bersama-sama.

\section{METODE}

Desain prosedur dalam perbaikan pembelajaran ini adalah Penelitian Tindakan Kelas (PTK). Menurut Faizah (2009: 99) penelitian tindakan kelas adalah suatu bentuk penelitian refleksi diri yang dilakukan oleh peserta peserta untuk meningkatkan penalaran. Menurut Suharsimi (2010: 16) bahwa PTK yang dilakukan melalui empat tahap. Setiap siklusnya yang dilakukan terdiri dari: tahap perencanaan (Planning), tahap pelaksanaan (Acting), tahap pengamatan (observing) dan tahap refleksi (reflecting).

Penelitian ini dilakukan sebanyak dua siklus yaitu siklus I dilakukan 4 kali pertemuan, setelah siklus I dilakukan ulangan harian 1 kali pertemuan. Siklus II dilakukan 6 minggu, setelah siklus II dilakukan ulangan harian 1 kali pertemuan. Kegiatan yang dilaksanakan pada masing-masing siklus sebagai berikut:

\section{Siklus I}

\section{a. Tahap Perencanaan}

Perencanaan penelitian untuk menerapkan model problem solving dilaksanakan pada semester ganjil pada bulan Agustus 2017 s.d bulan Oktober 2017. Proses pembelajaran dan tes ulangan harian dilakukan dalam laboratorium dan dalam ruang kelas.

\section{b. Tahap Pelaksanaan}

Pelaksanaan siklus I dimulai bulan Agustus 2017 selama 4 kali pertemuan untuk belajar dan 1 kali pertemuan ulangan harian dihari Senin dan Rabu. Peneliti sebagai guru di dalam kelas, sebagai perencana penelitian, observer, pengumpul data, analisis data dan pelapor hasil penelitian. Dalam penelitian juga dibantu oleh observer lain yaitu guru dengan mata pelajaran sejenis yaitu Elsa Farida, S.Pd.

Sebelum pembelajaran dimulai peserta didik diarahkan untuk bersyukur, mengabsen kehadiran peserta didik selanjutnya para peserta didik duduk dalam kelompok masing-masing. Kemudian guru menjelaskan kompetensi dasar, Indikator pembelajaran atau tujuan pembelajaran, Guru memperlihatkan memberi Lembaran Kerja Peserta Didik 
(LKPD) dan guru memberikan pengantar terhadap materi yang akan disampaikan menlalui peta konsep.

Proses pembelajaran yang dilakukan menggunakan model pembelajaran problem solving. Adapun Langkah-langkah model pembelajaran problem solving adalah:

1. Fase Orientasi peserta didik kepada masalah

2. Fase Mengorganisasikan peserta didik

3. Fase Membimbing penyelidikan individu dan kelompok

4. Fase Mengembangkan dan menyajika hasil karya

5. Fase Menganalisa dan mengevaluasi proses pemecahan masalah

\section{c. Tahap Pengamatan}

Data penelitian pada siklus I dikumpulkan observasi pembelajaran dan ulangan harian. Pengamatan dilakukan untuk mengetahui sejauh mana penerapan model pembelajaran problem solving dapat meningkatkan hasil belajar dalam memahami konsepkonsep fisika.

\section{d. Tahap Refleksi}

Dari hasil analisis data yang ditemukan pada siklus I diharapkan terjadi hal-hal berikut :

1. Dapat terjadi peningkatan hasil belajar dengan diterapkannya model pembelajaran problem solving.

2. Adanya peningkatan pemahaman peserta didik terhadap materi yang beraplikasi dalam kehidupan nyata dengan menggunakan model pembelajaran problem solving.

3. Melalui tahapan pada model pembelajaran problem solving diharapkan perubahan sikap peserta didik yang sebelum kurang tertarik dengan fisika, menjadi suka, kurang motivasi menjadi menyukainya, dan akhir pelajaran fisika bisa menjadi favorit dari peserta didik

4. Berdasarkan refleksi hasil belajar Fisika melalui model pembelajaran problem solving jika belum memuaskan pada siklus I maka perlu diperbaiki pada siklus II. 


\section{HASIL DAN PEMBAHASAN}

Hasil ulangan harian ke-1 untuk peserta didik dapat dilihat dalam tabel berikut ini:

Tabel 1 Hasil UH Peserta Didik Pada Siklus I

\begin{tabular}{cccccc}
\hline No & $\begin{array}{c}\text { Kriteria } \\
\text { Ketuntasan } \\
\text { Minimal } \\
(\text { KKM })\end{array}$ & $\begin{array}{c}\text { Jumlah } \\
\text { Peserta } \\
\text { didik }\end{array}$ & $\begin{array}{c}\text { Rata-rata } \\
\text { Nilai }\end{array}$ & $\%$ & Keterangan \\
\hline 1. & 74 & 20 & 76,00 & $60,1 \%$ & Tuntas \\
\hline 2. & 74 & 13 & 56,54 & $39,39 \%$ & Belum Tuntas \\
\hline
\end{tabular}

Dari Tabel 1 dapat dijelaskan bahwa jumlah peserta didik yang nilainya tuntas 20 orang $(60,1 \%)$ dengan kriteria "Cukup" dan jumlah peserta didik yang belum tuntas sebanyak 13 orang (39,39\%). Rata-rata ulangan harian untuk peserta didik yang tuntas 76,00 dengan nilai tertinggi 85 dan rata-rata ulangan harian yang belum tuntas 56,54 nilai terendah 40 (lampiran). Rata-rata nilai ulangan harian seluruhnya 68,33 kategori cukup.

Adapun sebaran nilai peserta didik pada siklus I dapat dilihat Tabel 2 berikut ini:

Tabel 2 Sebaran Nilai Peserta didik Pada siklus I

\begin{tabular}{cccc}
\hline \multirow{2}{*}{ No } & Interval Nilai & \multicolumn{2}{c}{ Peserta didik } \\
\cline { 2 - 4 } & nilai & $\begin{array}{c}\text { Jumla } \\
\mathrm{h}\end{array}$ & $\begin{array}{c}\text { Persentase( } \\
\%\end{array}$ \\
\hline 1 & 84 & 1 & $3,0 \%$ \\
\hline 2 & 70 & 19 & $57,6 \%$ \\
\hline 3 & 50 & 11 & $33,3 \%$ \\
\hline 4 & 0 & 2 & $6,1 \%$ \\
\hline
\end{tabular}


Belum tercapainya hasil belajar seperti yang diharapkan oleh karena hal- hal berikut ini:

1). Peserta didik baru pertama kali mengikuti model pembelajaran problem solving

2). Peserta didik lebih banyak membaca materi sehingga sulit memahami konsep/pemahaman fisika untuk mengkaitkannya dengan masalah dalam LKPD.

3). Kurangnya partisipasi peserta didik untuk memunculkan ide-ide dalam menyelesaikan Masalah dan dalam membuat kesimpulan.

\section{Refleksi Siklus I}

Dari data analisis data ditemukan hal-hal sebagai berikut:

1) Pada saat proses pembelajaran sedang berlangsung guru harus lebih banyak lagi berkeliling untuk mengawasi kegiatan berdiskusi pada setiap fase model pembelajaran problem solving sehingga peserta didik maksimal untuk memahami menyelesaikan dan membuat kesimpulan.

2) Guru harus mengarahkan peserta didik yang punya kemampuan lebih tinggi untuk aktif memberikan penjelasan kepada teman satu kelompok pada saat melakukan eksperimen dan menyelesaikan masalah

3) Waktu yang tersedia dalam diskusi terasa masih kurang, sehingga ada peserta didik belum siap untuk mengeluarkan ide-idenya dalam menyelesaikan masalah dan dalam membuat kesimpulan.

Berdasarkan pertimbangan terhadap hasil temuan pada siklus I, peneliti dan observer mengambil kesimpulan bahwa hasil belajar belum optimal dan dapat dilanjutkan ke siklus II.

\section{Kemajuan Penelitian Antar Siklus}

Mengamati kemajuan peningkatan hasil belajar untuk tiap siklus dapat dilihat pada tabel berikut ini: 
Tabel 3 Peningkatan Hasil Belajar Peserta didik

\begin{tabular}{ccc}
\hline \multirow{2}{*}{$\begin{array}{c}\text { Ketuntasan } \\
\text { Belajar }\end{array}$} & \multicolumn{2}{c}{ Tindakan } \\
\cline { 2 - 3 } & Siklus I ( \%) & Siklus II ( \% ) \\
\hline Tuntas & 20 orang $(60,1 \%)$ & 30 orang (91\%) \\
\hline Tidak Tuntas & 13 orang $(39,39 \%)$ & 81,51
\end{tabular}

Tabel 3 dapat disimpulkan terjadi peningkatan nilai rata-rata ulangan harian yaitu pada siklus I rata-ratanya 68,33 dengan kategori cukup, yaitu 20 peserta didik tuntas $(60,1 \%)$ dan 13 peserta didik belum tuntas $(39,39 \%)$ sementara pada siklus II rata-ratanya menjadi 81,51 dengan kategori baik yaitu 30 peserta didik tuntas (91\%) dan 3 peserta didik belum tuntas (9\%). Peningkatan hasil belajar dari siklus I ke siklus II ini menunjukkan bahwa model pembelajaran problem solving ini efektif untuk meningkatkan hasil belajar.

Untuk itu pada siklus II guru mengoptimalkan pembelajaran dengan cara selalu memberi pengawasan yang baik dan selalu mendatangi setiap kelompok sampai mereka nyaman dan percaya diri untuk melakukan setiap fase-fase pembelajaran dengan baik, guru juga tidak memburu-buru waktu tetapi mendampingi kalau ada yang belum dipahami. Tindakan perbaikan ini mendapat respon yang baik dari peserta didik dimana mereka lebih fokus dan lebih berani melakukan eksperimen dan menyampaikan ide-ide dalam memecahkan masalah walaupun diawal siklus II hasilnya masih belum optimal namun dengan proses yang berlanjut pemahaman peserta didik sudah semakin meningkat dengan baik.

Pada siklus ke II ini guru juga selalu mengingat agar dalam kelompok tidak ada persaingan tetapi diharapkan peserta didik yang memiliki kemampuan yang lebih mengajari temannya yang masih belum memahami apa yang didiskusikan sehingga semua peserta didik dapat saling menguatkan. Guru mengarahkan persaingan yang sehat terjadi hanya saat ulangan harian, dimana guru membimbing perlunya kerja sama saat menyelesaikan masalah namun perlu bersaing saat ulangan harian sehingga peserta didik juga diarahkan harus jujur. Seperti yang disampaikan Sanjaya (2008: 31) bahwa persaingan 
yang sehat dapat memberikan pengaruh yang baik untuk proses pembelajaran peserta didik.

Dari tes ulangan harian yang dilakukan pada siklus II diperoleh hasilnya dengan kategori baik yaitu 30 orang (91\%) tuntas dari peserta didik 33 orang dan hanya 3 orang (9\%) yang perlu perbaikan atau remedial dan nilai rata-ratanya adalah 81,51 . Hasil pada siklus II ini sudah sesuai seperti yang diharapakan oleh peneliti, hal ini tidak terlepas dari pengawasan dan pembimbingan yang dilakukan guru yaitu dengan selalu mendatangi/ berkeliling tiap kelompok saat melakukan kegiatan demi kegiatan dan menanyakan hal-hal yang masih meragukan buat peserta didik saat berdiskusi karena jika pemahaman yang berkembang dalam kelompok keliru maka akan sulit meningkatkan ke pemahaman selanjutnya.

Pada siklus II terjadi perubahan-perubahan dimana semangat belajar peserta didik lebih baik, lebih aktif dan kreatif serta pembelajaran lebih kondusif. Suasana saat presentasi juga berjalan baik dimana para peserta didik sudah mengikuti bahkan banyak yang memberi tanggapan, usulan untuk menyelesaikan masalah yang dibahas. Konsep fisika yang mereka dapat melalui eksperimen dan diskusi lebih mudah direalisasikan karena teman dalam kelompok mau saling berbagi. Guru juga berperan aktif memacu motivasi peserta didik untuk membangun pengetahuannya dengan memberikan ide-ide pemecahan masalah yang sesuai dengan kehidupan sehari-hari.

Selain itu guru selalu memotivasi bahwa mereka mampu menyelesaikan setiap soal-soal dalam LKPD dan mendorong peserta didik memiliki pengetahuan bukan menghapal tetapi memahami dengan membangun pengetahuan dari menemukan sendiri saat aktif menanggapi presensi kelompok lain dimana setiap peserta didik dapat saling melengkapi pengetahuan mereka.

Seirama dengan pendapat Sanjaya (2008: 260) bahwa "belajar bukanlah menghafal akan tetapi proses mengkonstruksi pengetahuan sesuai dengan pengalaman yang mereka miliki, oleh karena itu semakin banyak pengalaman maka akan semakin banyak pula pengetahuan yang mereka peroleh".

Sanjaya juga berpendapat bahwa belajar adalah "proses pemecahan masalah sebab dengan memecahkan masalah anak akan berkembang secara utuh yang bukan hanya perkembangan intelektual akan tetapi juga mental dan emosi dan pada akhirnya anak akan siap menghadapi setiap persoalan. Guru selalu berusaha agar peserta didik merasa hebat dan mampu dimana guru memberi pujian yang sewajarnya kepada yang bertanya dan memberi tanggapan. Sanjaya (2008: 31) mengatakan semua peserta didik membutuhkan penghargaan baik dengan komentar misalkan dengan perkataan "bagus" atau "teruskan 
pekerjaanmu", karena komentar positif dapat meningkatkan motivasi dan semangat belajar peserta didik.

Dari hasil analisis diatas tergambar bahwa model pembelajaran problem solving efektif untuk meningkatkan pengetahuan dan cocok dilaksanakan sehingga peserta didik memiliki pemahaman yang baik tentang konsep fisika. Selain itu model pembelajaran problem solving mampu mengembang pemikiran para peserta sehingga memiliki keterampilan sains yang baik. Seirama dengan pendapat Riyanto (2009: 308) bahwa proses pembelajaran problem solving merangsang berpikir peserta didik dan mampu mengembangkan kemandirian belajar sekaligus belajar bersama dengan kelompoknya. Hal ini dikuatkan oleh Pendapat Nasution (2009:85) bahwa "masalah itu harus rill yang ada kaitannya dengan murid, sehingga ada hasrat dan kesediaan untuk memecahkannya".

Pembelajaran yang bertumpu pada penyelesaian masalah memberikan kesempatan kepada siswa untuk menganalisa dan mendiskusikan pemecahan masalah, walaupun sebenarnya guru sudah mempersiapkan apa yang harus dibahas dan bagaimana menyelesaikan masalah tersebut namun proses pembelajaran selalu diarahkan agar siswa mampu menyelesaikan masalah secara sistematis dan logis. Dari hasil pembahasan di atas peneliti melihat efektifitas model pembelajaran problem solving berdampak baik dan dapat dilanjutkan untuk mengembangkan Kegiatan Belajar Mengajar (KBM) khususnya mata pelajaran Fisika di SMAN 6 Pekanbaru.

\section{SIMPULAN DAN SARAN}

\section{simpulan}

Berdasarkan hasil temuan, analisis data dan pembahasan hasil penelitian dapat ditemukan kesimpulan bahwa model pembelajaran problem solving dapat meningkatkan semangat belajar peserta didik khususnya pembelajaran fisika. Peningkatan hasil belajar fisika dari 68,33 pada siklus I menjadi 81,51 pada siklus II. Peningkatan hasil belajar peserta didik meningkat secara singnifikan dengan bertambahnya peserta didik yang tuntas atau nilainya dari 20 orang $(60,1 \%)$ pada siklus I menjadi 30 orang (91\%) pada siklus II. Dari alasan diatas menunjukkan bahwa model pembelajaran problem solving efektif meningkatkan hasil belajar dan tentunya juga menunjukkan mampu meningkatkan motivasi belajar peserta didik kelas XI. IPA.2 SMAN 6 Pekanbaru.

\section{Saran}

Berdasarkan kesimpulan dalam penelitian ini, maka penulis menyarankan sebagai berikut : 
1. Model Pembelajaran problem solving dapat dijadikan sebagai alternatif dalam pembelajaran fisika, karena dapat membantu peserta didik untuk mengkonstruksi pengetahuannya

2. Guru hendaknya harus aktif dan kreatif dalam menyiapkan membimbing dan mengarahkan peserta didik ketika menggunakan model pembelajaran problem solving.

3. Dalam pelaksaan model pembelajaran problem solving guru harus selalu mengawasi secara berkala dan ketat agar siswa nyaman selama belajar dan selalu siap dengan berbagai pertanyaan dari para peserta didik yang berkaitan antara konsep fisika dengam masalah dalam kehidupan sehari-hari. 


\section{DAFTAR PUSTAKA}

Arikunto suharsimi, Suhardjoho, Supardi, (2010) Penelitian Tindakan Kelas.Bumi Aksara. Jakarta

Faizah Hasnah (2009), Menulis Karangan Ilmiah, Cendikia Insani. Pekanbaru

Hamzah, (2010) Teori Motivasi dan Pengukurannya Analisis di Bidang Pendidikan, Bumi Aksara, Jakarta

J. Mursell dan Nasution, (2008). Mengajar Dengan Sukses (Successful Teaching). Bumi Aksara, Jakarta

Riyanto Yatim, (2009) Paradigma Baru Pembelajaran Sebagai Referensi Guru/Pendidik Dalam Implementasi Pembelajaran Yang Efekktif dan Berkualitas ,Kencana Prenada Medis Group Jakarta.

Sanjaya, (2008). Strategi Pembelajaran Berorientasi Standar Proses Pendidikan. Kencana Prenada Media Group, Jakarta

Suharto, (2015): Materi Pelatihan Guru Implementasi Kurikulum 2013 Tahun 2015 SMA/SMK 